\title{
A New Antibiotic-Producing Bacterium from Seawater: Alteromonas aurantia sp. nov.
}

\author{
M. J. GAUTHIER AND VIOLETTE A. BREITTMAYER \\ Centre d'Etudes et de Recherches de Biologie et d'Océanographie Médicale, Institut National de la Santé et \\ de la Recherche Médicale, Unité 40, Nice, France
}

\begin{abstract}
Six strains of gram-negative, polarly flagellated, antibiotic-producing marine bacteria that synthesize an orange, noncarotenoid pigment were submitted to an extensive phenotypic characterization. All of them had properties characteristic of the genus Alteromonas. Two strains were closely related to Pseudomonas piscicida. The others could be considered as members of a new species for which the name Alteromonas aurantia is proposed. The type strain of A. aurantia is strain 208 (= ATCC $33046=$ NCMB 2052).
\end{abstract}

Three recently characterized marine species of Alteromonas-A. luteoviolaceus (10), A. rubra (11), and A. citrea (13) - synthesize polyanionic antibiotics which act on bacterial respiration $(12,14)$ and produce violacein, prodigiosin, and a yellow, noncarotenoid pigment, respectively. In addition, several phenotypic features differentiate them from the other members of this genus as described by Baumann et al. (2), Reichelt and Baumann (21), and Chan et al. (9).

Further investigations on the antibacterial activity of marine bacteria commonly found in Mediterranean waters led us to isolate a number of orange-pigmented strains, some of which share phenotypic and genetic characters of the genus Alteromonas. These strains are described in the present report, and their taxonomic position is discussed.

\section{MATERIALS AND METHODS}

Bacterial strains. Six strains were examined in this study. They were placed in the collection of the Centre d'Etudes et de Recherches de Biologie et d'Océanographie Médicale under the numbers 57, 201, 202, 206, 207, and 208 and in the American Type Culture Collection (ATCC) as ATCC 33041, ATCC 33042, ATCC 33043, ATCC 33044, ATCC 33045, and ATCC 33046, respectively. Strains 57, 201, and 208 were deposited in the National Collection of Marine Bacteria (NCMB) (Torry Research Station, Aberdeen Scotland) under the numbers 2049, 2033, and 2052, respectively.

Strains 57, 201, 206, and 208 were obtained from surface seawater off Nice, France; the others were isolated from the surface of seaweeds (Ulva lactuca) harvested in the same area. All of the strains were isolated on marine agar (MA; Difco) and were selected for study on the basis of their antibiotic activity and their pigmentation, as previously described (13).

Methods. The methods and media used for the phenotypic characterization of strains were previously described $(10,11,13)$. These methods were modified as follows.

The pigments were separated by high-pressure liquid chromatography using water-acetonitrile-tetrahydrofuran-acetic acid (55:35:10:1) with detection at 436 nm.

Besides the 60 organic compounds used in the previous studies on $A$. rubra (11) and $A$. citrea (13), the following additional substrates were employed: 9methyl xyloside, methyl-D-mannoside, methyl-D-glucoside, $N$-acetyl glucosamine, amygdalin, arbutin, esculin, L-sorbose, D-melibiose, D-turanose, D-lyxose, Dtagatose, D-fucose, D-arabitol, xylitol, $\beta$-gentobiose, Larabitol, glycogen, 2-ketogluconate, 5-ketogluconate, L-isoleucine, L-norleucine, L-valine, DL-norvaline, Lserine, L-methionine, L-tyrosine, L-citrulline, trigonelline, $L$-aspartate, DL-kinurenine, betaine, creatine, $\alpha$ alanine, DL-2 aminobutyrate, DL-3-aminobutyrate, DL4-aminobutyrate, DL-5-aminovalerate, DL-2-aminobenzoate, DL-3-aminobenzoate, DL-4-aminobenzoate, acetamide, sarcosine, ethylamine, butylamine, amylamine, ethanolamine, benzylamine, diaminobutane, spermine, histamine, and tryptamine.

Susceptibility to the following eight antibiotics was determined with Bio-Discs (BioMérieux, Marcy l'Etoile, France) (amount of antibiotic per 6-mm-diameter in parentheses): gentamycin $(10 \mu \mathrm{g})$, pristinamycin $(15 \mu \mathrm{g})$, spiramycin $(100 \mu \mathrm{g})$, tobramycin $(10 \mu \mathrm{g})$, lincomycin $(2 \mu \mathrm{g})$, doxycycline $(30 \mu \mathrm{g})$, ampicillin (10 $\mu \mathrm{g})$, and cephaloridin $(30 \mu \mathrm{g})$. Strains were deemed susceptible when the width of the inhibition ring was greater than $5 \mathrm{~mm}$, slightly susceptible when it was less than $5 \mathrm{~mm}$, and completely resistant when there was no visible inhibition. The susceptibilities of strains 57 , 206,207 , and 208 to pteridin $0 / 129$ was determined on $\mathrm{MA}$ and that of strains 201 and 202 was determined on Mueller-Hinton medium (Institut Pasteur, Paris).

The abilities of the strains to hydrolyze chitin, sodium alginate, and collagen were determined by the methods of Brisou (4), Baumann et al. (1), and Hanada et al. (15), respectively.

The guanine plus cytosine $(\mathrm{G}+\mathrm{C})$ content of the deoxyribonucleic acid (DNA) was determined by the thermal denaturation technique (19) after extraction of the DNA by the method described by Marmur (18). 


\section{RESULTS}

Morphology. The cells of the six strains were gram-negative, straight rods with rounded ends ( 0.5 to $1.5 \mu \mathrm{m}$ in width and 1.5 to $4 \mu \mathrm{m}$ in length). Each cell was motile by means of a single polar flagellum (Fig. 1 and 2). After 5 to 6 days at $23^{\circ} \mathrm{C}$ in all media tested, motility, along with vitality, decreased.

Cultural characteristics. The six strains were strictly aerobic: none of them could grow in an oxygen-free atmosphere.

On MA, colonies of the six strains were small ( $1 \mathrm{~mm}$ in diameter), bright, and uniformly pale yellow after $24 \mathrm{~h}$ at $23^{\circ} \mathrm{C}$. Their center then turned to orange. After 5 days, colonies of strains $57,206,207$, and 208 (group 1) were circular (3 to $4 \mathrm{~mm}$ in diameter), regular, convex, bright, and smooth with a brownish orange center and a large, greenish edge (one third of the radius); older colonies became greenish brown. No diffusible pigment was produced in the medium. Variants with uniformly bright orange colonies
(6 to $7 \mathrm{~mm}$ in diameter) occurred with a frequency of 1 variant for every 500 to 1,000 colonies. The colonies of strains 201 and 202 (group 2) were larger ( 4 to $6 \mathrm{~mm}$ in diameter) but less pigmented (uniformly pale orange) than those of the other strains. The addition of starch to the medium $(5 \%$, wt/vol) produced an increase in colony size for all of the strains and in the pigmentation of strains of group 2 only.

On blood-MA, all strains produced bright, mucoid, dark-brown colonies, and after 2 or 3 days the medium around them turned black. Each colony was surrounded by a ring of partial hemolysis. Strain 207 gave off a typical cyanide odor.

On tryptic soy agar and on nutrient agar (Difco) prepared with distilled water and $2 \%$ $\mathrm{NaCl}$ (wt/vol), only strains 201 and 202 grew, producing small, pale yellow colonies. On these media prepared with seawater, strains of group 1 gave rise to small orange colonies. A greenish pigment appeared in the colonies when these media contained ferric phosphate $(0.1 \%, \mathrm{wt} / \mathrm{vol})$.
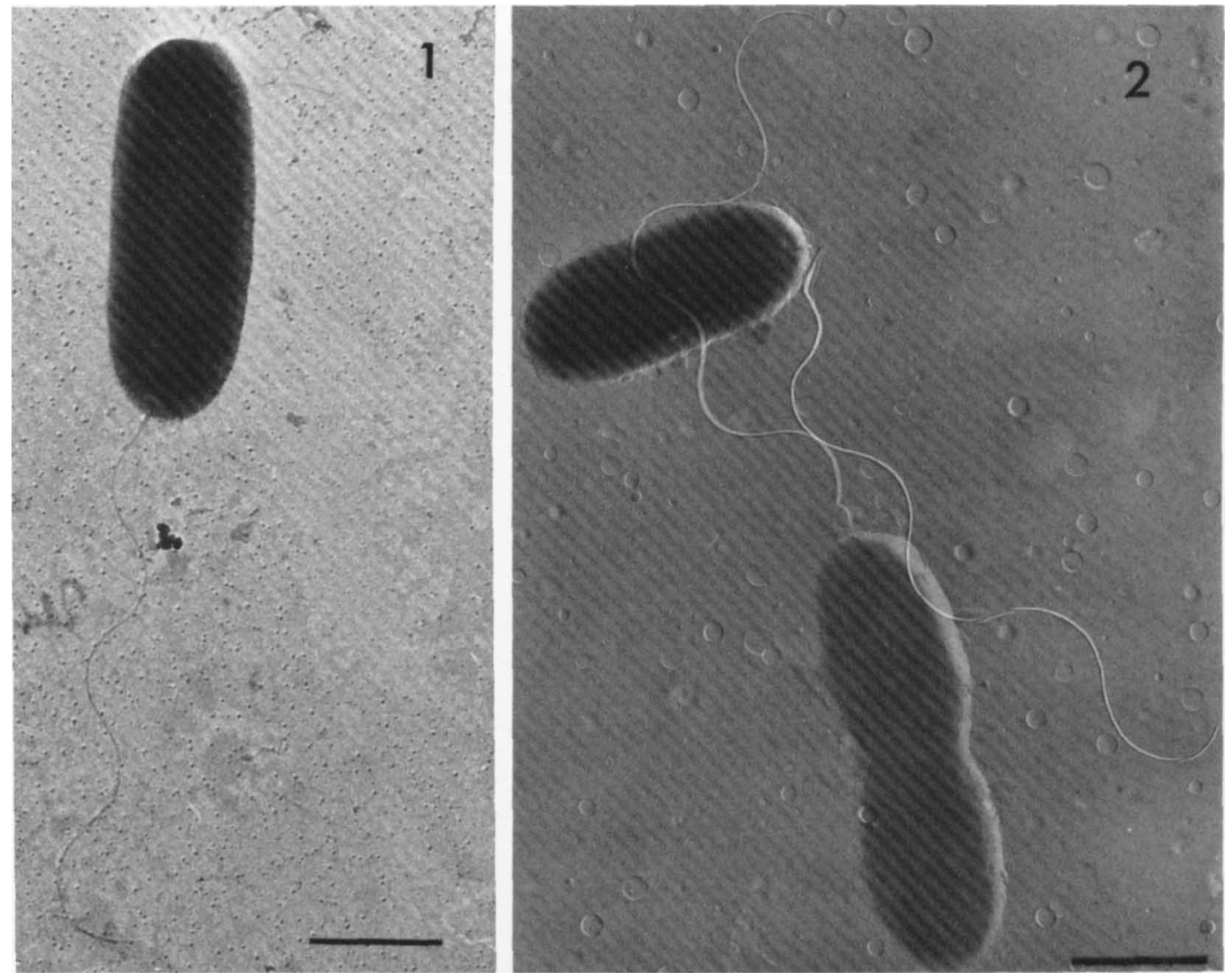

Fig. 1-2. Electron micrographs of cells of strains 201 (= ATCC 33042) and 208 (= ATCC 33046), respectively. Bars represent $1 \mu \mathrm{m}$. 
Strains 201 and 202 produced small, pale yellow colonies, the color of which did not change in the presence of ferric phosphate. None of the strains produced diffusible pigments in these media.

On King medium A (17) prepared with seawater, strains $57,206,207$, and 208 produced large, conical, orange-pigmented colonies ( 5 to 6 $\mathrm{mm}$ in diameter) with a brown, central mucro. On the same medium, strains 201 and 202 gave bright orange colonies and produced an abundant, diffusible yellow pigment that was not present in strains of group 1. On King medium $\mathrm{B}$, only strains 201 and 202 were able to grow, producing large (5 to $6 \mathrm{~mm}$ in diameter) whitish colonies and a diffusible brownish orange pigment.

In marine broth (Difco) at $23^{\circ} \mathrm{C}$, growth of the six strains occurred in the top centimeter only. Each strain produced a thick, crackled, orange-red pellicle, an orange ring that adhered to the glass, and a slight, yellowish sediment.

In the gelatin (Difco) stab prepared with seawater, infundibuliform liquefaction took place rapidly $(24 \mathrm{~h})$ around the stab. The hydrolysate was a clear, colorless fluid for strains of group 1 and a strongly turbid liquid for strains of group 2.

Temperature, pH, salinity, and sodium requirements. The strains of groups 1 and 2 differed greatly in their ability to grow at different temperatures, $\mathrm{pH}$, and salinities. In the former group, strains were able to grow at 4 to 30 . $\mathrm{C}$, to tolerate $\mathrm{pH}$ values from 6 (57 and 206) or 7 (207 and 208) to 10 (207 and 208) or 11 (57 and 206), and to grow in artificial seawater media with salinities from 10 to $80 \%$ (112\% for strain
57). Strains of group 2 were more tolerant to these conditions: they could grow at temperatures from 15 to $44^{\circ} \mathrm{C}$, at $\mathrm{pH}$ values from 5 to 11 , and with salinities 5 to $112 \%$.

Only strains of group 1 required $\mathrm{Na}^{+}$for growth (Fig. 3); despite a slight difference for strain 57 , they were inhibited by $\mathrm{Na}^{+}$concentrations lower than $0.3 \mathrm{M}$ and higher than $0.8 \mathrm{M}$. Their maximum growth occurred with concentrations of 0.5 to $0.6 \mathrm{M} \mathrm{Na}^{+}$. Strains 201 and 202 were able to grow in a sodium-free medium, but their growth was strongly enhanced by low concentrations of that ion. They were not inhibited by $1.5 \mathrm{M} \mathrm{Na}^{+}$.

Antibiotic production. Strains of group 1 produced a polyanionic antibiotic similar to those synthesized by $A$. rubra, A. luteoviolaceus, and $A$. citrea. On the basis of the dialysis experiments, the antibiotic produced by strains 201 and 202 appears to be a rather small molecule.

Antibiotic synthesis was constant whatever the $\mathrm{pH}$ and temperature, but it was strongly activated in media supplemented with starch $(5 \%, \mathrm{wt} / \mathrm{vol})$, particularly with strains of group 2. In all cases, a total lack of activity was observed in cells grown on blood-containing media; this phenomenon was previously found in $A$. rubra and $A$. citrea and was explained by the catalase activity of blood $(11,13)$.

Pigment production. All six strains produced a noncarotenoid, orange pigment in seawater media; the pigment was more abundant in the presence of starch for strains of group 2. This pigment was readily soluble in methanol, ethanol, and acetone, slightly soluble in water, and insoluble in chloroform. The ultraviolet-vis-

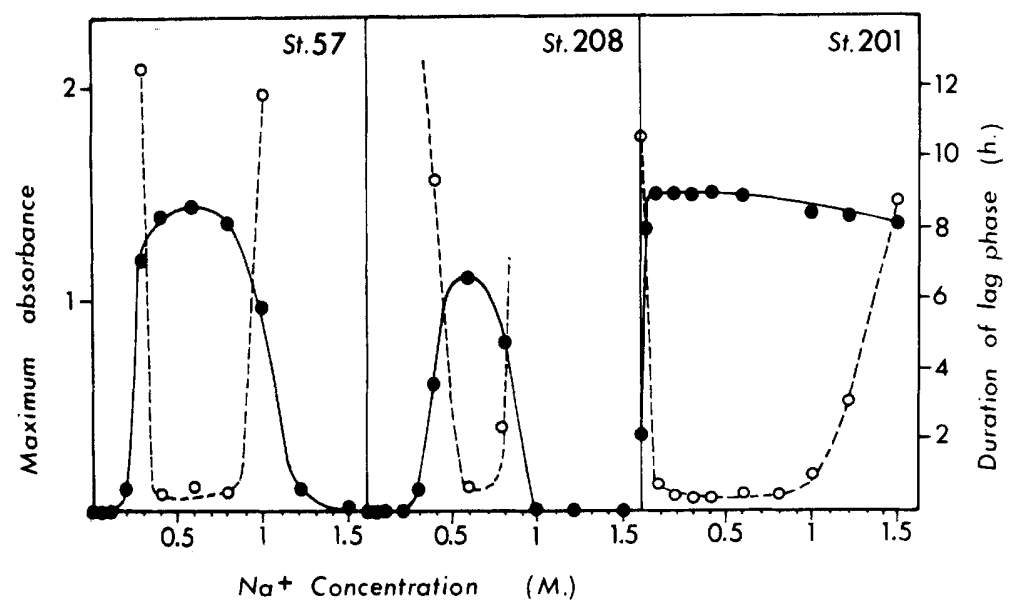

FIG. 3. Effects of sodium on growth of strains 57,201 (= ATCC 33042), and 208 (= ATCC 33046), tested in a marine medium (13) incubated at $23^{\circ} \mathrm{C}$. Symbols: 0 , maximum absorbance of cultures; $\bigcirc$, duration of lag phase. 
ible absorption spectra of chloroform-methanol extracts of the pigments ( $\mathrm{pH} \mathrm{6.8)}$ were markedly different for groups 1 and 2: group 1 strains had an absorption maximum at $396 \mathrm{~nm}$, and group 2 strains, had one at $376 \mathrm{~nm}$ (Fig. 4). These pig= ments were composed of several fractions which could be separated chromatographically. Highpressure liquid chromatographs (Fig. 5) showed that strains of group 1 produced a closely related

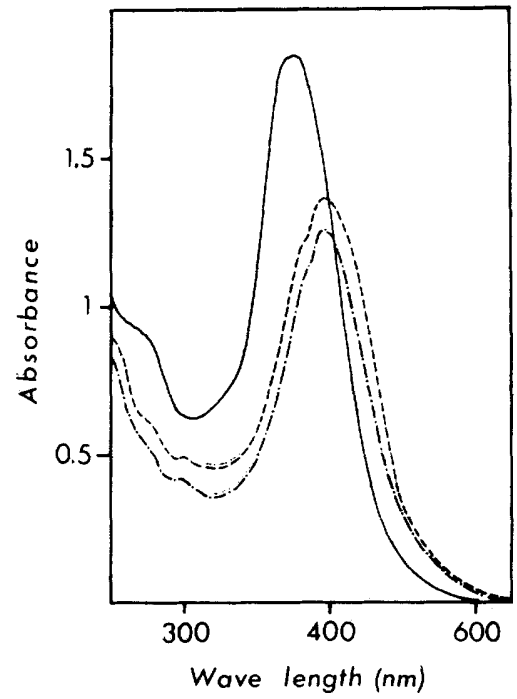

Fig. 4. Ultraviolet visible absorption spectra of crude chloroform-methanol (1:1) extracts of the pigments produced by strains $57(-\cdot-\cdot-\cdot), 201(-)$, and 208 (----). mixture of yellow and orange fractions, whereas strains 201 and 202 mainly synthesized only one of these fractions.

Range of organic compounds utilized. Of the 112 organic substrates tested, only glucose, mannose, trehalose, glucosamine, $\mathrm{N}$-acetylglucosamine, arginine, and L-tyrosine were utilized by the six strains as sole sources of carbon. In addition, the four strains of group 1 utilized Dfructose, Tween 20 , Tween 80 , and ascorbate, and strains 201 and 202 used maltose, saccharose, starch, glycogen, methyl-D-mannoside, leucine, isoleucine, citrulline, succinate, fumarate, malate, pyruvate, and citrate. A few substrates were sparsely used: maltose (208), starch (57), leucine $(57,208)$, hístidine $(201,208)$, citrulline (207), methionine (201), phenylalanine (201), proline (201), and amylamine (201). Therefore, the main difference between groups 1 and 2 is the ability of the latter to utilize intermediary metabolites of the tricarboxylic acid cycle.

Enzyme production. All of the strains possessed the following enzymes: oxidase, catalase, cytochrome oxidase, peroxidase, amylases, acid phosphatase, alkaline phosphatase, deoxyribonuclease, phospholipase C, tween esterases, tributyrate lipase, gelatinases (trypsin-like enzymes), collagenase, leucine aminopeptidase, valine aminopeptidase, and phosphoamidase. Only strains of group 1 showed a marked cystine aminopeptidase activity, and only strains 201 and 202 possessed chitinase, $\alpha$-glucosidase, $\beta$ glucosaminidase, and chymotrypsin-like gelatinases. None of the six strains produced nitrate reductase, arginine dihydrolase, urease, alginase,

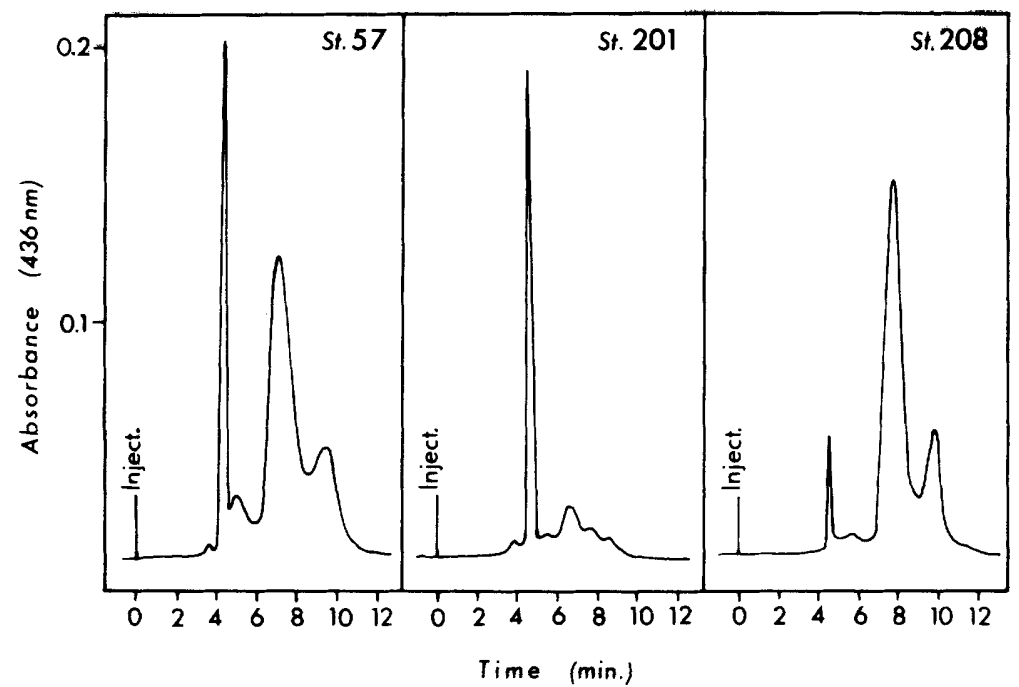

Fig. 5. Fractionation of the chloroform-methanol (1:1) extract of strains 57, 208 (= ATCC 33046), and 201 (= ATCC 33042) by high-pressure liquid chromatography. 
TABLE 1. Main characters which distinguish Alteromonas aurantia from the previously named species of Alteromonas ${ }^{i}$

\begin{tabular}{|c|c|c|c|c|c|c|c|c|c|c|}
\hline Character & 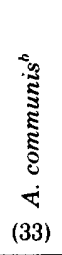 & 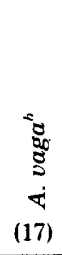 & 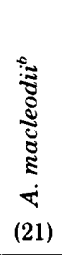 & 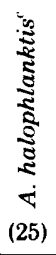 & 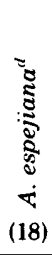 & 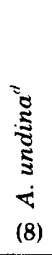 & 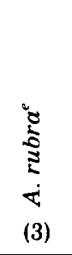 & 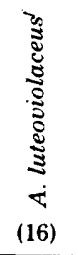 & $\begin{array}{l}\text { है } \\
\vdots \\
\vdots \\
0 \\
\text { (3) }\end{array}$ & 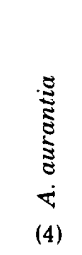 \\
\hline $\mathrm{G}+\mathrm{C}$ content (mol\%) of DNA & 47 & 48 & 46 & 43 & 43 & 43 & 47 & 42 & 42 & $39-42$ \\
\hline Straight rods ${ }^{h}$ & - & + & + & + & + & - & + & + & + & + \\
\hline Ring cleavage $^{i}$ & $\mathbf{m}$ & $\mathbf{m}$ & - & - & - & - & - & $\mathrm{ND}^{j}$ & - & - \\
\hline Oxidase & + & - & + & + & + & + & + & + & + & + \\
\hline Growth at $35^{\circ} \mathrm{C}$ & + & + & + & 21 & 8 & - & + & + & 1 & - \\
\hline Growth at $40^{\circ} \mathrm{C}$ & + & - & 15 & - & - & - & - & - & 1 & - \\
\hline Amino acid(s) required for growth & - & - & - & 6 & + & + & + & ND & + & + \\
\hline Amylase(s) & - & - & 19 & 4 & + & 5 & + & 15 & + & + \\
\hline Gelatinase(s) & - & - & 20 & + & + & + & + & + & + & + \\
\hline Lipase(s) & - & - & + & + & + & + & + & + & + & + \\
\hline Alginase & - & - & 3 & - & + & - & ND & ND & ND & - \\
\hline Chitinase & - & - & - & 16 & - & + & - & - & - & - \\
\hline \multicolumn{11}{|l|}{ Use of: } \\
\hline D-Mannose & 29 & + & - & 21 & 12 & - & + & - & + & + \\
\hline D-Galactose & 11 & 15 & + & 5 & + & - & - & ND & - & - \\
\hline Sucrose & - & 1 & + & 23 & + & + & - & - & - & - \\
\hline Cellobiose & - & 14 & + & - & 9 & - & - & - & - & - \\
\hline Melibiose & - & - & 20 & - & + & - & ND & ND & ND & - \\
\hline Lactose & - & - & + & 1 & + & - & - & - & - & - \\
\hline Salicin & - & - & + & - & - & - & - & ND & - & - \\
\hline D-Gluconate & + & + & 18 & 1 & - & - & - & ND & - & - \\
\hline$N$-Acetylglucosamine & - & 15 & 7 & 23 & - & + & ND & ND & ND & + \\
\hline Succinate & + & + & - & + & - & + & - & ND & - & - \\
\hline Fumarate & + & + & - & + & - & + & - & ND & - & - \\
\hline DL-Glycerate & 4 & - & + & - & - & - & ND & ND & ND & - \\
\hline Citrate & + & + & - & 21 & 17 & - & - & ND & - & - \\
\hline Aconitate & + & 16 & - & 21 & 17 & - & ND & ND & ND & - \\
\hline Erythritol & - & + & - & - & - & - & - & ND & - & - \\
\hline Mannitol & + & + & 9 & 11 & + & - & - & - & - & - \\
\hline Glycerol & + & + & + & - & - & - & - & - & - & - \\
\hline$\gamma$-Aminobutyrate & + & 16 & - & - & - & - & ND & ND & ND & - \\
\hline L-Tyrosine & - & - & 18 & 23 & + & + & ND & ND & ND & + \\
\hline $\left.\begin{array}{l}\text { Sorbitol, DL-malate, } \\
\alpha \text {-ketoglutarate, } \\
m \text {-hydroxybenzoate }\end{array}\right\}$ & + & + & - & - & - & - & - & ND & - & - \\
\hline Pigmentation & - & - & - & - & - & - & $t^{k}$ & $+^{t}$ & $+^{m}$ & $t^{n}$ \\
\hline
\end{tabular}

a Symbols: +, all strains positive; -, all strains negative; numbers indicate number of positive strains; boldfaced numbers indicate that the number represents $80 \%$ or more of the strains. Most of these data are taken from Baumann and Baumann (in M. P. Starr, H. Stolp, H. G. Trüper, A. Balows, and H. G. Schlegel, (ed.), in press). Numbers in parentheses indicate number of strains studied.

${ }^{b}$ Data from Baumann et al. (2).

'Data from Baumann et al. (2) and Reichelt and Baumann (21).

${ }^{d}$ Data from Chan et al. (9).

'Data from Gauthier (11).

${ }^{f}$ Data from Gauthier (10).

g Data from Gauthier (13).

${ }^{h}$ Symbols: +, straight rods; -, curved rods.

${ }^{i}$ Mechanism of aromatic ring cleavage by species capable of growth on aromatic compounds.

${ }^{j} \mathrm{ND}$, Not determined.

${ }^{k}$ Prodigiosin.

'Violacein.

${ }^{m}$ Lemon-yellow, non-carotenoid pigment.

${ }^{n}$ Orange, non-carotenoid pigment. 
tryptophanase, tryptophane deaminase, phenylalanine deaminase, $\alpha$ - or $\beta$-galactosidases, $\beta$ glucuronidase, $\alpha$-mannosidase, $\alpha$-fucosidase, C. 14 lipase, or lysine or ornithine decarboxylase.

Susceptibility to inhibitors. (i) Antibiotics. All strains were susceptible to erythromycin, chloramphenicol, thiophenicol, polymyxin, colistin, gentamycin, rifamycin, vancomycin, oleandomycin, and tobramycin; moderately susceptible to streptomycin, staphylomycin, pristinamycin, neomycin, novobiocin, kanamycin, and spiramycin; and completely resistant to bacitracin, lincomycin, doxycycline, and cephaloridin. In addition, only strains 201 and 202 were inhibited by penicillin $\mathrm{G}$, ampicillin, tetracycline, and chlortetracycline.

(ii) Vibriostatic pteridin 0/129. All of the strains were resistant to pteridin $0 / 129$. However, in the case of strains of group 1 , this observation could be an artifact due to the use of a medium with a high salt content (20).

(iii) Respiratory inhibitors. All strains were strongly inhibited by acriflavin and 8-hydroxyquinoline and were resistant to lysozyme, urethane, and antimycin A. Only strains of group 2 were susceptible to rotenone, and only strain 207 was completely resistant to $700 \mu \mathrm{g}$ of $\mathrm{KCN}$.

Miscellaneous reactions. The six strains were unable to utilize DL-hydroxybutyrate and did not accumulate its polymer. None of them produced $\mathrm{H}_{2} \mathrm{~S}$, gave a positive methyl red or Voges-Proskauer reaction, hydrolyzed esculin, or produced trimethylamine from trimethylamine oxide. All of the strains rapidly hydrolyzed casein. Only strains of group 2 reduced methylene blue.

DNA base composition. The $\mathrm{G}+\mathrm{C}$ contents of the DNA's of strains 57,201,202, 206, 207, and 208 were $42.2,44.4,44.2,42.5,40.8$, and 38.8 $\mathrm{mol} \%$, respectively.

\section{DISCUSSION}

The six strains studied are strictly aerobic, polarly flagellated, gram-negative, rod-shaped organisms with low $\mathrm{G}+\mathrm{C}$ contents in their DNAs (39 to $44 \mathrm{~mol} \%$ ). They are of marine origin and require $\mathrm{Na}^{+}$for growth. These properties allow their placement in the genus Alteromonas (2). Nevertheless, strains of groups 1 and 2 differ considerably from the presently known alteromonads with respect to their phenotypic characters.

Most of the morphological, cultural, and physiological characteristics of strains 201 and 202 indicate that these strains resemble Pseudomonas piscicida (Bein) Buck et al., originally named Flavobacterium piscicida by Bein (3) but subsequently regarded as a member of the genus Pseudomonas on the basis of further studies by Weeks et al. (22), Buck et al. (6), and Hansen et al. (16). Although their toxicity to fish was not investigated in this study, strains 201 and 202 showed an antibacterial activity comparable to the antiyeast properties of $P$. piscicida reported by Buck and Meyers $(7,8)$. On the basis of the G+C value of the DNA, P. piscicida should be excluded from the genus Pseudomonas, as indicated in the 8th edition of Bergey's Manual (5), and be reassigned to the genus Alteromonas (M.S. Hendrie and J.M. Shewan, personal communication).

Strains 57, 206, 207, and 208 (group 1) are different from the previously characterized $\mathrm{Al}$ teromonas species (Table 1). Their main phenotypic features closely resemble those of $A$. citrea. However, they have slightly lower $\mathrm{G}+\mathrm{C}$ values, produce an orange pigment, and lack tryptophane and phenylalanine deaminases. They can be considered as a distinct, new species, for which the name Alteromonas aurantia is proposed (au.ran'tia. M.L. noun aurantium, the orange; M.L. fem. adj. aurantia, gold-colored). Strain 208 ( $=$ ATCC $33046=$ NCMB 2052 ) is designated as the type strain of the species.

\section{ACKNOWLEDGMENTS}

We thank P. Baumann and M.S. Hendrie for their interest and advice during the course of this study.

We are also grateful to D.M. Gibson (Torry Research Station, Aberdeen, Scotland) for his help and determination of the DNA base ratios and to G. Torpier (Service de microscopie électronique, Institut Pasteur, Lille, France), who performed the electron microscopy.

\section{REPRINT REQUESTS}

Address reprint requests to: Dr. M.J. Gauthier, C.E.R.B.O.M., 1 Avenue Jean Lorrain, 06300 Nice, France.

\section{LTTERATURE CITED}

1. Baumann, P., L. Baumann, and M. Mandel. 1971. Taxonomy of marine bacteria: the genus Beneckea. J. Bacteriol. 107:268-294.

2. Baumann, L., P. Baumann, M. Mandel, and R. D. Allen. 1972. Taxonomy of marine eubacteria. J. Bacteriol. 110:402-429.

3. Bein, J. S. 1954. A study of certain chromogenic bacteria isolated from "red tide" water with a description of a new species. Bull. Mar. Sci. Gulf Caribb. 4:110-119.

4. Brisou, J. 1971. Techniques d'enzymologie bactérienne. Masson \& Cie, Paris.

5. Buchanan, R. E., and N. E. Gibbons. 1974. Bergey's manual of determinative bacteriology, 8 th ed. The Williams \& Wilkins Co., Baltimore.

6. Buck, J. D., S. P. Meyers, and E. Leifson. 1963. Pseu. domonas (Flavobacterium) piscicida Bein comb. nov. J. Bacteriol. 86:1125-1126.

7. Buck, J. D., and S. P. Meyers. 1966. In vitro inhibition of Rhodotorula minuta by a variant of the marine bacterium Pseudomonas piscicida. Helgol. Wiss. Meeres unters. 13:171-180.

8. Buck, J. D., and S. P. Meyers. 1966. Growth and phos- 
phate requirements of Pseudomonas piscicida and related antiyeast pseudomonads. Bull. Mar. Sci. 16:93101 .

9. Chan, K. Y., L. Baumann, M. M. Garza, and P. Baumann. 1978. Two new species of Alteromonas: Alteromonas espejiana and Alteromonas undina. Int. J. Syst. Bacteriol. 28:217-222.

10. Gauthier, M. J. 1976. Morphological, physiological, and biochemical characteristics of some violet pigmented bacteria isolated from seawater. Can. J. Microbiol. 22: 138-149.

11. Gauthier, M. J. 1976. Alteromonas rubra sp. nov., a new marine antibiotic-producing bacterium. Int. J. Syst. Bacteriol. 26:459-466.

12. Gauthier, M. J. 1976. Modification of bacterial respiration by a polyanionic antibiotic produced by a marine Alteromonas. Antimicrob. Agents Chemother. 9:361366.

13. Gauthier, M. J. 1977. Alteromonas citrea, a new gramnegative, yellow-pigmented bacterium isolated from seawater. Int. J. Syst. Bacteriol. 27:349-354.

14. Gauthier, M. J., and G. N. Flatau. 1976. Antibacterial activity of marine violet pigmented Alteromonas with special reference to the production of brominated cor. pounds. Can. J. Microbiol. 22:1612-1619.

15. Hanada, K., T. Mitzumani, M. Tamagashi, M. Tamai, H. Tsuji, T. Misaki, and J. Sawada. 1971. Studies on collagenase of a marine bacterium. Part 1 . The isolation and determination of microorganisms producing collagenase. Agric. Biol. Chem. 35:1651-1659.

16. Hansen, A. J., A. Ingebritsen, and O. B. Weeks. 1963. Flagellation of Flavobacterium piscicida. J. Bacteriol. 86:602-604.

17. King, E. O., M. K. Ward, and D. E. Raney. 1954. Two simple media for the demonstration of pyocyanin and fluorescein. J. Lab. Clin. Med. 44:305-307.

18. Marmur, J. 1961. A procedure for the isolation of deoxyribonucleic acid from microorganisms. J. Mol. Biol. 3: 208-218.

19. Marmur, J., and P. Doty. 1962. Determination of the base composition of deoxyribonucleic acid from its thermal denaturation temperature. J. Mol. Biol. 5:109-118.

20. Merkel, J. R. 1972. Influence of salts on the vibriostatic action of 2,4 diamino -6,7- diisopropyl pteridine. Arch. Microbiol. 81:379-382.

21. Reichelt, J. L., and P. Baumann. 1973. Change of the name Alteromonas marinopraesens (ZoBell and Upham) Baumann et al. to Alteromonas haloplanktis (ZoBell and Upham) comb. nov. and assignment of strain ATCC 23821 (Pseudomonas enalia) and strain c-A1 of De Voe and Oginski to this species. Int. J. Syst. Bacteriol. 23:438-441.

22. Weeks, O. B., S. M. Beck, M. D. Thomas, and H. D. Isenberg. 1962. Pigment of Flavobacterium piscicida. J. Bacteriol. 84:1118. 